\title{
Autonomic Dysreflexia: Are Physicians Aware?
}

\section{Otonom Disrefleksi: Hekimler Farkında mı?}

\author{
(D) Bilinç Doğruöz Karatekin,, (1) Sadiye Murat,, (1) Derya Demirbağ Kabayel, ${ }^{2}$ \\ (D) Selçuk Yavuz, ${ }^{3}$ (D) Filiz Tuna, ${ }^{2}$ (1) Yasemin Yumuşakhuylu, ${ }^{4}$ (D) Afitap Iç̧ağasıoğlu ${ }^{4}$
}

${ }^{1}$ Department of Physical Medicine and Rehabilitation,

Istanbul Medeniyet

University Goztepe Prof

Dr Suleyman Yalcin City

Hospital, Istanbul, Turkey

2Department of Physical

Medicine and Rehabilitation,

Trakya University Faculty of

Medicine, Edirne, Turkey

${ }^{3}$ Department of Physical

Medicine and Rehabilitation,

Lüleburgaz Medical Center,

Kırklareli, Turkey

${ }^{4}$ Department of Physical

Medicine and Rehabilitation,

Istanbul Medeniyet

University Faculty of

Medicine, Istanbul, Turkey

Cite this article as: Doğruöz

Karatekin B, Murat S,

Demirbağ Kabayel D, Yavuz S,

Tuna F, Yumuşakhuylu Y, et al.

Autonomic Dysreflexia: Are

Physicians Aware? Bosphorus

Med J 2021;8(Suppl: 1):19-23.

Received: 17.04 .2021

Accepted: 17.05.2021

Correspondence: Dr. Bilinç Doğruöz Karatekin.

Department of Physical

Medicine and Rehabilitation,

Istanbul Medeniyet

University Goztepe Prof

Dr Suleyman Yalcin City

Hospital, Istanbul, Turkey

Phone:

+905368308709

e-mail:

bilincdogruoz@hotmail.com

OPEN ACCESS

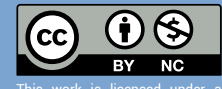

\section{ABSTRACT}

Objectives: In this study, it was aimed to investigate the awareness and treatment approaches of physicians in autonomic dysreflexia (AD), which is a clinical syndrome that can cause serious complications in patients with spinal cord injury $(\mathrm{SCl})$.

Methods: This study is a cross-sectional survey study. A questionnaire was filled by face-to-face interviews with 121 physicians from different branches who are likely to encounter patients with $\mathrm{SCl}$, who are on duty in emergency services.

Results: Of the participants, $55.4 \%$ stated that they heard the term and $44.6 \%$ of those marked the correct definition in the next question. Only $15.7 \%$ of the participants marked the correct answer of the criteria for hypertension in patients with $\mathrm{SCl}$. About $30 \%$ of the participants have no idea about the first approach to hypertension in $\mathrm{SCl}$ patients or first approach to AD clinic.

Conclusion: The group of physicians who will work in the emergency department should have an appropriate training program in the residency training curriculum on $\mathrm{AD}$ and $\mathrm{SCl}$ complications. The knowledge of physicians working in the emergency department regarding the diagnosis, management, and also the specialty to be consulted regarding $A D$ is quite limited.

Keywords: Autonomic dysreflexia; awareness; emergency; spinal cord injury

\section{ÖZET}

Amaç: Bu çalışmada, omurilik yaralanması (OY) hastalarında ciddi komplikasyonlara neden olabilen klinik bir sendrom olan Otonomik Disrefleksi (OD) konusunda hekimlerin farkındalıklarının ve tedavi yaklaşımlarının araştıılması amaçlanmıştır.

Yöntem: Bu çalışma, kesitsel bir anket çalışmasıdır. Acil servislerde görevli omurilik yaralanmalı hastalarla karşılaşma ihtimali olan farklı branşlardan 121 hekim ile yüz yüze görüşülerek anket dolduruldu.

Bulgular: Katılımcıların \%55.4'ü OD terimini duyduğunu belirtti ve OD terimini duyan katılımcıların \%44.6'sı bir sonraki soruda doğru tanımı işaretledi. Omurilik yaralanması olan hastalarda hipertansiyon kriterlerinin doğru cevabını katıımcıların sadece \%15.7'si işaretledi. Katılımcıların \%30'unun OY hastalarında hipertansiyona ilk yaklaşım veya OD kliniğine ilk yaklaşım hakkında hiçbir fikri yoktur.

Sonuç: Acil serviste çalışacak hekim grubunun uzmanlık eğitimi müfredatında, OD ve OY komplikasyonları konusunda uygun bir eğitim planlanı olmalıdır. Acil serviste çalışan hekimlerin OD'nin tanısı, yönetimi ve danışılacak uzmanlık konusundaki bilgileri oldukça sınırlıdır.

Anahtar sözcükler: Acil; farkındalık; otonom disrefleksi; omurilik yaralanması.

utonomic dysreflexia (AD) is a potentially - life-threatening hypertensive medical emergency that occurs as a result of uncontrolled sympathetic activity triggered by a noxious or nonnoxious sensory stimulus below the injury level in those with spinal cord lesions at or above the
T6 level. ${ }^{[1]}$ In addition to the anatomo-pathological changes due to spinal cord lesions, changes in the functioning, and control of the autonomic nervous system also play an important role in the pathophysiology. Sensory disinhibition, increased activity due to sympathetic system disin- 
hibition, reflex responses in sympathetic postganglionic neurons, re-innervation of sympathetic postganglionic neuron interneurons, and denervation hypersensitivity causing sensitivity in $\alpha$-adrenergic receptors constitute the pathophysiological basis of AD. ${ }^{[2]}$ In 1947, Guttmann and Whitteridge described for the first case that viscera distension induces an autonomic response in a patient with spinal cord injury (SCI) by stimulating profound effects on cardiovascular activity. ${ }^{[3]}$

Lifetime prevalence in patients with SCI of T6 and above is reported to be between $20 \%$ and $70 \% .{ }^{[4]}$ Although AD is seen in the chronic phase of the injury, after the spinal shock period is over, it can occur at any time following the injury. In general, the first attack is seen within about 6 months after SCI. However, in $5.2 \%$ of the cases, it can be seen in the 1 st months. ${ }^{[5,6]}$

The key to early diagnosis in an episode of AD is suspicion. Because despite high blood pressure, symptoms may remain silent. Half of the patients who had an attack describe the trio of throbbing headache, excessive sweating, and flushing. ${ }^{[7]}$ Hypertension is the definitive criterion of AD. It should be kept in mind that basal systolic and diastolic BP in patients with high-level SCI is approximately $15 \mathrm{mmHg}$ lower than healthy individuals. An increase of $20-40 \mathrm{mmHg}$ according to the patient's basal BP (increase in systolic BP by $20 \%$ or more) should be a warning for the $\mathrm{AD}$ attack. Sudden and severe increase in blood pressure can lead to $\mathrm{AD}$ complications such as convulsion-epileptic seizure, focal neurological deficits, visual impairment, hypertensive encephalopathy, subarachnoid/intracerebral hemorrhage, retinal hemorrhage, cardiac arrhythmia, acute myocardial failure, and neurogenic pulmonary edema that can lead to death. ${ }^{[8]}$

Treatment of $\mathrm{AD}$ involves detecting and eliminating the triggers, controlling symptoms, and preventing complications. When an individual at risk is encountered with one or more of the symptoms, the patient should be approached with suspicion, and the diagnosis of AD should be made with the detection of high blood pressure. Physicians who may encounter with these patients should be aware of the potential problems that develop $\mathrm{AD}$ and their treatments.

In this study, it was aimed to investigate the awareness and treatment approaches of physicians in $\mathrm{AD}$, which is a clinical syndrome that can cause serious complications in patients with SCI.

\section{Methods}

This study is a cross-sectional survey study. A questionnaire was filled by face-to-face interviews with physicians from different branches who are likely to encounter patients with spinal cord injuries, who are on duty in emergency services.

The questionnaire was prepared by a rehabilitation physician experienced in SCI. It composed of questions including demographic information, the definition of $\mathrm{AD}$, clinical findings, and treatment. Physicians were first questioned whether they encountered a patient with SCI, and the study was conducted with the physicians who did. The questions asked in the questionnaire are shown in Table 1.

\section{Table 1. Questions of the questionnaire about awareness of AD}

$\begin{array}{ll}1 & \text { You came across a patient with SCI. There is a clinic of headache, facial rash, sweating, and blurred vision. What would you do first. } \\ 2 & \text { What are your thoughts on blood pressure values in patients with high level SCI? } \\ 3 & \text { Does the approach to hypertension observed in patients with SCI differ from hypertension in the general population? } \\ 4 & \text { What is the criterion for referring to hypertension in patients with SCI? } \\ 5 & \text { You have detected hypertension in the patient with SCl. What would you do first? } \\ 6 & \text { What would you inquire about in this patient first? } \\ 7 & \text { What would be the limit for medical therapy for persistent systolic blood pressure in this patient? } \\ 8 & \text { Which medical treatment would you prefer first? } \\ 9 & \text { What would you suggest to empty this patient's bladder? } \\ 10 & \text { Have you ever heard of the term autonomic dysreflexia before? } \\ 11 & \text { What do you think autonomic dysreflexia is? } \\ 12 & \text { What could be the things you think might trigger the autonomic dysreflexia? } \\ 13 & \text { Is this clinic a life-threatening condition that requires emergency intervention? } \\ 14 & \text { Does the level of SCl have any significance in the emergence of this clinic? } \\ 15 & \text { Would you consider requesting an PMR consultation while the patient was in AD clinic? }\end{array}$


Research ethics approval was obtained from University Ethics Committee (Approval Decision No: 31/J). All physicians gave written informed consent.

Statistical analysis was conducted using the Statistical Package for the Social Sciences Version 22.0 (SPSS Inc., Chicago,IL, USA). Demographic and clinical data were compared by descriptive analysis, mean \pm standard deviation (minimum-maximum) values for continuous variables and frequency values (number of cases), and percentages for categorical variables.

\section{Results}

The study was conducted with 121 physicians who agreed to answer the questionnaire. Of the participants $25.6 \%$ were internal medicine physician, $21.5 \%$ were family physician, 9.9\% were emergency care physician, and $43 \%$ were other (neurology, neurosurgery, orthopedics, ENT, pulmonary medicine, etc.) physicians. The mean age of the participants was $33.3 \pm 8.2$. The demographic information of the participants is given in Table 2 .

In the first question and the $5^{\text {th }}$ question, what physicians would do first in the case of $\mathrm{AD}$ and hypertension detected in SCI patients was asked. The responses of the participants are shown in Table 3.

Only $15.7 \%$ of the participants marked the correct answer of the criteria for hypertension in patients with SCI. Likewise, $46.3 \%$ of the participants gave the answer "I have no idea" to the question "Does the approach to hypertension observed in patients with SCI differ from hypertension in the general population?”

In the question of the first choice of drug in persistent hypertension in SCI patients, 34.7\% of the participants answered captopril, 19.8\% nitroprusside, $8.6 \%$ nifedipine, $7.4 \%$ furosemide, and $29.4 \%$ answered as "I had no idea."

In the $10^{\text {th }}$ and $11^{\text {th }}$ questions of the questionnaire, the participants were asked whether they heard the term $\mathrm{AD}$ and knew its definition. About $55.4 \%$ of the participants stated that they heard the term and $44.6 \%$ of those marked the correct definition in the next question.

In the $13^{\text {th }}$ question, the participants were asked whether they knew that AD was a life-threatening emergency or not. While $57.9 \%$ of the participants said yes, $37.2 \%$ stated that they had no idea.
Table 2. Demographic characteristics of the participants

\begin{tabular}{|c|c|c|}
\hline & Min-Max & Mean $\pm S D$ \\
\hline Age (years) & $24-64$ & $33.33 \pm 8.26$ \\
\hline Year in the specialty & $0-30$ & $3.72 \pm 6.89$ \\
\hline \multirow[t]{2}{*}{ Year in the medicine } & $1-39$ & $8.83 \pm 8.33$ \\
\hline & $\mathbf{n}$ & $\%$ \\
\hline \multicolumn{3}{|l|}{ Gender } \\
\hline Female & 52 & 43 \\
\hline Male & 69 & 57 \\
\hline \multicolumn{3}{|l|}{ Specialty } \\
\hline Emergency medicine & 12 & 9.9 \\
\hline Internal medicine & 31 & 25.6 \\
\hline Family medicine & 26 & 21.5 \\
\hline Neurology & 7 & 5.8 \\
\hline Neurosurgery & 4 & 3.3 \\
\hline Orthopedics & 8 & 6.6 \\
\hline ENT & 6 & 5.0 \\
\hline Plastic surgery & 3 & 2.5 \\
\hline Radiology & 2 & 1.7 \\
\hline Infectious diseases & 7 & 5.8 \\
\hline Pulmonary medicine & 7 & 5.8 \\
\hline Pulmonary surgery & 3 & 2.5 \\
\hline General surgery & 3 & 2.5 \\
\hline Dermatology & 2 & 1.7 \\
\hline \multicolumn{3}{|l|}{ Title } \\
\hline Resident & 81 & 66.9 \\
\hline Specialist & 33 & 27.3 \\
\hline Ass. Prof & 7 & 5.8 \\
\hline
\end{tabular}

Table 3. First approaches of the participants to AD and hypertension in SCl patients

\begin{tabular}{|c|c|c|}
\hline \multirow[t]{2}{*}{ Answer } & \multicolumn{2}{|c|}{$\begin{array}{l}\text { First approach in } \\
\text { AD clinic }\end{array}$} \\
\hline & $\mathbf{n}$ & $\%$ \\
\hline Measuring blood pressure & 52 & 43 \\
\hline Consultation to neurosurgery & 26 & 21.5 \\
\hline Consultation to neurology & 13 & 10.7 \\
\hline No idea & 30 & 24.8 \\
\hline \multirow[t]{2}{*}{ Answer } & \multicolumn{2}{|c|}{$\begin{array}{l}\text { First approach in } \\
\text { hypertension in } \\
\text { SCI patient }\end{array}$} \\
\hline & $\mathbf{n}$ & $\%$ \\
\hline Positioning & 9 & 7.4 \\
\hline Medical treatment & 46 & 38 \\
\hline $\begin{array}{l}\text { Consultation to internal } \\
\text { medicine or cardiology }\end{array}$ & 30 & 25 \\
\hline No idea & 36 & 29.8 \\
\hline
\end{tabular}

AD: Autonomic Dysreflexia, SCl: Spinal cord injury. 
In the $12^{\text {th }}$ question, it was asked whether the participants knew the triggers of AD or not. Participants' responses are shown in Figure 1.

While $65.3 \%$ of the participants said that the level of SCI is important in the development of $\mathrm{AD}, 33.1 \%$ said they had no idea.

Participants were asked whether they would request a PMR consultation from a patient in an AD clinic. Only $12.4 \%$ of the participants answered yes, 57.9\% answered no and $28.9 \%$ stated that they had no idea.

\section{Discussion}

After SCI at T6 and above, the clinical picture characterized by a strong, persistent sympathetic discharge against a noxious stimulus and the persistent hypertension attack caused by this is called AD. Although there are various theories in its pathophysiology, "aberrant sympathetic overactivity" is the most accepted theory. ${ }^{[2]}$

It is very important to know the clinical features of $\mathrm{AD}$, because if recognized, it can be treated successfully, otherwise it can lead to serious medical problems or even death. In this study, the awareness of physicians working in the emergency department, who may encounter $\mathrm{AD}$, about the diagnosis and management of $\mathrm{AD}$ was investigated.

According to the results of the study, only half of the participants heard the term $\mathrm{AD}$, and only half of the participants who heard it marked the definition correctly.

After the diagnosis of $\mathrm{AD}$, the underlying life-threatening reversible factors should be eliminated immediately. The most important of the systems that trigger $\mathrm{AD}$ is the genitourinary

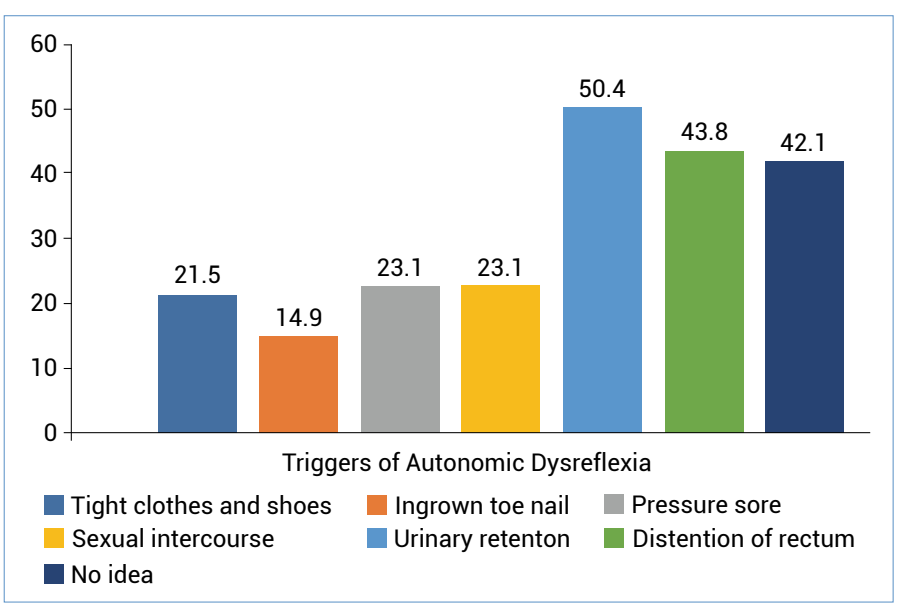

Figure 1. Answers of the participants about triggers of autonomic dysreflexia (\%). system. One of the most common causes of AD is bladder distention. Bladder distention is responsible for $85 \%$ of episodes. ${ }^{[9]}$ The second most common AD trigger is rectal distention. Fecal impact is responsible for approximately $13-19 \%$ of the cases. ${ }^{[10]}$ Fractures, pressure sores, tight clothing and burns, ingrown toenails, men's, trauma, DVT, pulmonary embolism, and drugs (decongestants, especially misoprostol) are other causes of AD. ${ }^{[11]}$ In this study, only half of the participants correctly marked urinary retention, which is the most common of the AD triggers, and the recognition rate of other triggers was much lower.

It has been reported in the literature that many family medicine physicians have also limited knowledge of SCI management and are uncomfortable in the treatment of these patients. ${ }^{[12-14]}$ Also in this study, the majority of the physicians working in the emergency department were family medicine physicians and internal medicine physicians. One reason for this result may be that $80 \%$ of the participants were resident. On the other hand, group of physicians who will work in the emergency department should have an appropriate training program in the residency training curriculum on $\mathrm{AD}$ and $\mathrm{SCI}$ complications.

The knowledge of physicians working in the emergency department regarding the diagnosis, management and also the specialty to be consulted regarding AD is quite limited. Only 12\% of the physicians consider seeking PMR consultation when encountering $\mathrm{AD}$. This number is very low considering $\mathrm{AD}$ can be considered as an emergency of rehabilitation medicine.

In our literature review, we did not find a similar study on physicians' awareness of SCI complications and AD. This study is the first to reveal the insufficient knowledge of physicians on this subject. Appropriate action should be taken by the relevant authorities in this regard.

\section{Limitations}

This study is a cross-sectional study and all physicians working in the emergency department in a specific period were included in the study. The results of the study are single center results and cannot be generalized. In future studies, it is recommended to evaluate different branches such as emergency department physicians and family physicians individually and by considering the distinction between specialists and residents. 


\section{Conclusion}

$\mathrm{AD}$ is a life-threatening, emergency clinical condition. Since it can be controlled with rapid diagnosis and easy treatment methods, it is of great importance for physicians to recognize and manage $\mathrm{AD}$ clinic. As a result of the survey, it was observed that the physicians working in the emergency department did not have enough information about AD.

\section{Disclosures}

Etik Kurul Onayı: Research ethics approval was obtained from University Ethics Committee (Approval Decision No: 31/J).

Peer-review: Externally peer-reviewed.

Conflict of Interest: None declared.

Authorship Contributions: Concept - B.D.K., S.M., S.Y.; Design - S.M., S.Y.; Supervision - D.D.K., F.T., A.I.; Materials - B.D.K., S.M., S.Y., F.T., D.D.K., Y.Y., A.I.; Data collection \&/or processing - B.D.K., S.M., S.Y., F.T., D.D.K., Y.Y., A.I.; Analysis and/or interpretation - B.D.K., S.M.; Literature search - B.D.K., S.M.; Writing - B.D.K., S.M.; Critical review - S.Y., F.T., D.D.K., A.I., Y.Y.

\section{References}

1. Krassioukov AV, Karlsson AK, Wecht JM, Wuermser LA, Mathias CJ, Marino RJ. Assessment of autonomic dysfunction following spinal cord injury: Rationale for additions to international standards for neurological assessment. J Rehabil Res Dev 2007;44:103-12.

2. Claydon VE, Krassioukov AV. Orthostatic hypotension and autonomic pathways after spinal cord injury. J Neurotrauma 2006;23:1713-25.

3. Guttmann L, Whitteridge D. Effects of bladder distension on autonomic mechanisms after spinal cord injuries. Brain 1947;70:361-404.

4. Helkowski WM, Ditunno JF Jr., Boninger M. Autonomic dysreflexia: Incidence in persons with neurologically complete and incomplete tetraplegia. J Spinal Cord Med 2003;26:244-7.

5. Krassioukov AV, Furlan JC, Fehlings MG. Autonomic dysreflexia in acute spinal cord injury: An under-recognized clinical entity. J Neurotrauma 2003;20:707-16.

6. Silver JR. Early autonomic dysreflexia. Spinal Cord 2000;38:22933.

7. Allen KJ, Leslie SW. Autonomic Dysreflexia. Treasure Island, FL: StatPearls Publishing LLC; 2021.

8. Hou S, Rabchevsky AG. Autonomic consequences of spinal cord injury. Compr Physiol 2014;4:1419-53.

9. Shergill IS, Arya M, Hamid R, Khastgir J, Patel HR, Shah PJ. The importance of autonomic dysreflexia to the urologist. BJU Int 2004;93:923-6.

10. Cosman BC, Vu TT, Plowman BK. Topical lidocaine does not limit autonomic dysreflexia during anorectal procedures in spinal cord injury: A prospective, double-blind study. Int J Colorectal Dis 2002;17:104-8.

11. Eldahan KC, Rabchevsky AG. Autonomic dysreflexia after spinal cord injury: Systemic pathophysiology and methods of management. Auton Neurosci 2018;209:59-70.

12. Middleton JW, Leong G, Mann L. Management of spinal cord injury in general practice part 1. Aust Fam Physician 2008;37:22933.

13. Donnelly C, McColl MA, Charlifue S, Glass C, O’Brien P, Savic $\mathrm{G}$, et al. Utilization, access and satisfaction with primary care among people with spinal cord injuries: A comparison of three countries. Spinal Cord 2007;45:25-36.

14. McColl MA, Forster D, Shortt SE, Hunter D, Dorland J, Godwin $\mathrm{M}$, et al. Physician experiences providing primary care to people with disabilities. Healthc Policy 2008;4:e129-47. 